\title{
EREBEA
}

Revista de Humanidades

y Ciencias Sociales

Núm. 4 (2014), pp. 299-324

ISSN: 0214-0691

\section{REYES, GENERALES Y ESCLAVOS: la Antigüedad Clásica A través del CiNe}

\author{
Marcos Rafael Cañas Pelayo \\ Antonio Míguez Santa Cruz \\ Universidad de Córdoba
}

RESUMEN

Los grandes personajes de la Antigüedad han solido evocar una fuerte atracción al medio cinematográfico. Sin embargo, abarcar este tipo de biografía en el celuloide ha supuesto en no pocas ocasiones, un verdadero quebradero de cabeza para directores, productores e intérpretes.

A lo largo del presente artículo, pretendemos mostrar las diferentes aproximaciones a cuatro de estos personajes de diferentes épocas (Alejandro Magno, Aníbal Barca, Espartaco y Cleopatra), muy representativos de su contexto, para ver cómo ha ido evolucionando la forma de representarlos en la gran pantalla. Atenderemos no solamente a contextos históricos, sino a estilos de representación, formas de narrarlo y visiones e ideologías que se realizaron a través de estos personajes que en muchos casos han alcanzado la categoría de mitos en el subconsciente popular.

Palabras Clave

Cine, Antigüedad, leyendas, versiones y mitos.

Fecha de recepción: 22 de abril de 2014

Fecha de aceptación: 23 de octubre de 2014

\section{Abstract}

The great historical characters of antiquity have often caught the attention of the cinema. The biography of such figures in cinema, however, has posed great problems for directors, producers, and actors.

In the present article we compare different versions of four important personages in antiquity: Alexander the Great, Hannibal Barca, Spartacus, and Cleopatra. We find that these figures are portrayed in different ways, depending on the creator who sought to represent them on the screen. Our focus is not only on the historical context of representation, but also on the technical aspects of cinema, style, forms of narration, and ideological vision.

KEYWORDS

Cinema, antiquity, biography, legends, myth. 

Figuras como Julio César, Atila, Boudicca o Nefertiti suelen evocar el recuerdo de un pasado remoto y fascinante para el gran público. No obstante, solamente una audiencia más especializada podrá ubicarlos concretamente en sus distintas épocas, por lo que toda difusión siempre es interesante, especialmente en un medio de masas del alance del cine.

Tradicionalmente, hacer mención de estos temas, supone una inmediata asociación con los términos de péplums, "cine de romanos" o género bíblico, asociado en su emisión a períodos tales como fiestas navideñas o Semana Santa. No obstante, como esperamos mostrar durante el presente artículo, se trata de una temática que encorseta mucho menos de lo que imaginamos a sus autores. No es lo mismo el Alejandro Magno de Oliver Stone que el de Theodoros Angelopoulos, como veremos a continuación.

Recurriremos también a bibliografías y fuentes, pero no tanto desde la perspectiva del rigor o no de las cintas, sino tratando de entender por qué se tomó tal o cuál decisión o qué objetivos se pretendían al mostrar la figura de determinado personaje con una luz distinta. En muchos casos, más que errores académicos, se escondían verdaderas y claras metas artísticas, políticas, ideológicas y de otra índole.

Hemos seleccionado para ello cuatro protagonistas formidables, aunque la lista podría haber sido mucho más amplia y los escogidos otros. Pese a ello, creemos que son exponentes claros de la idea que pretendemos reflejar y, con ellos, contamos con la inestimable ventaja de que son algunos de los que más veces han congregado en la gran pantalla a generaciones de espectadores.

El primero de ellos es la figura de Alejandro Magno, uno de los grandes conquistadores de todos los tiempos y protagonista indiscutible de uno de los primeros intentos de fusión de las

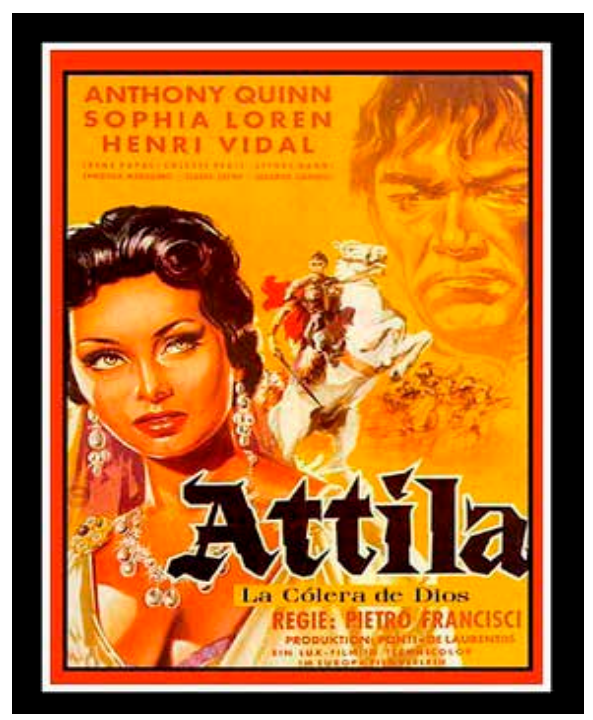

Atila Hombre o demonio (1954) 
culturas occidental y oriental a través de la conexión de la civilización griega con el Imperio Persa Aqueménida. Figura controvertida y ambivalente, sigue siendo objeto de discusión y fascinación, aún hoy.

Posteriormente abordaremos la biografía de Aníbal Barca, el gran general de Cartago y uno de los mejores militares de todos los tiempos. A diferencia de nuestros otros reseñados, el púnico aún adolece de una gran producción o dirección con la suficiente sensibilidad para aproximarnos a la verdadera dimensión de su período.

Seguidamente, la rebelde imagen de Espartaco, verdadero mito que ha sido tan utilizado por la propaganda soviética como demanda de guionistas norteamericanos contra la caza de brujas del senador McCarthy. Próxima en los años pero lejana en lo geográfico, finalizaremos con Cleopatra, última reina independiente de lo que fue el Imperio Egipcio y para la leyenda, exponente de la sexualidad exótica y una de las pocas gobernantes femeninas de la Antigüedad bien conocida y tratada.

"El SEÑor de las diez mil almas": La dificultad de Alexandrós

En un reciente estudio biográfico, Adrian Goldsworthy afirmaba que muy pocos personajes de ficción habían hecho lo que Cayo Julio César ${ }^{1}$. Era una metáfora elocuente de cómo algunos de los grandes personajes de la época clásica parecen haber tenido unas vidas casi inabarcables para tratarse en todas sus dimensiones y facetas, ya sea en un estudio, una novela o un largometraje.

¿Cómo no habrá sido impresio-

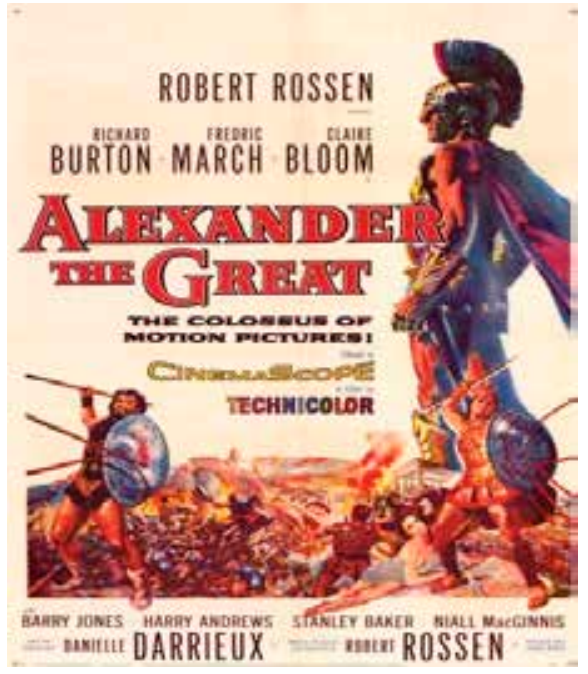

Alejandro Magno (1956) nante el reto para los cineastas que se han aproximado a la figura del ídolo del propio César, Alejandro Magno? Sabida es la anécdota de que el futuro dictador de Roma había llorado amargamente al ver una estatua del monarca macedonio en Gades, comprendiendo que cuando éste contaba con su edad, 30 años, ya había hecho perdurar su nombre para siempre por sus hazañas.

Nacido en el año 356 en la Corte de Pella, hijo del monarca Filipo II y la más importante de sus muchas esposas, Olimpia de Épiro, Alejandro estaba destinado a convertirse en uno de los grandes caudillos griegos, por su com-

1 A. Goldsworthy, César. Madrid: La Esfera de los Libros, 2007. 
pleja personalidad, su círculo familiar y, fundamentalmente, su caudillaje de las polis helenas para la conquista del Imperio Persa (entrando triunfalmente en el palacio del Gran Rey en Susa a la altura del 330).

Resulta lógico pensar que Hollywood tardase relativamente poco en rescatar su figura a través de una gran súper-producción para la época, Alexander The Great (1956). Escrita y dirigida por Robert Rossen, la película supone 135 minutos de entretenimiento y aventuras, centrados especialmente en la campańa en suelo persa, la más famosa del macedonio.

El encargado de encarnar al mítico conquistador no es otro que una de las grandes estrellas de la taquilla del momento, Richard Burton, quien posteriormente parecería especializarse en este tipo de héroes, siendo también Marco Antonio como veremos en un futuro epígrafe y ya habiendo encarnado al patricio Marcelo Galio en La túnica sagrada (1953), de un corte más bíblico que de época.

Con un decorado de cartón-piedra y en technicolor, la estética del film es la propia de la clase de péplum que tan característicos eran de los estudios norteamericanos. Rodado en buena parte en España, la obra es una clásica historia de aventuras, fiel a los acontecimientos principales, pero que no aborda temas más espinosos e interesantes como la verdadera sexualidad del protagonista ${ }^{2}$.

A diferencia de otros proyectos de similar ambientación como Ben-Hur, la visión de Rossen evita tocar, ni siquiera indirectamente, la homosexualidad de Alejandro y sus conocidas relaciones con su camarada Hefestión o el eunuco persa Bagoas. A pesar de tener sus méritos, da la sensación de que la obra podría ser de cualquier otro héroe de péplum, y que Alejandro fuera solamente la excusa para narrar la sucesión de batallas y conquistas.

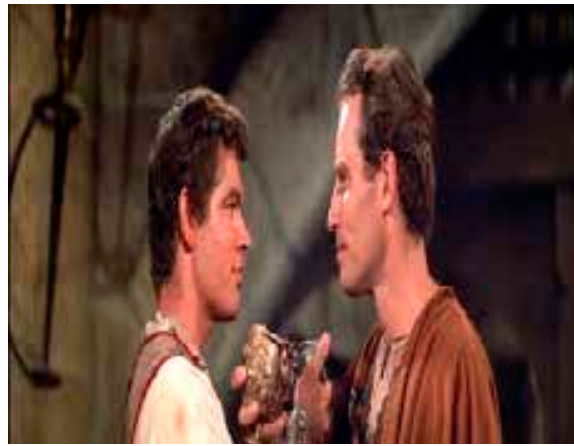

Ben-Hur (1959)

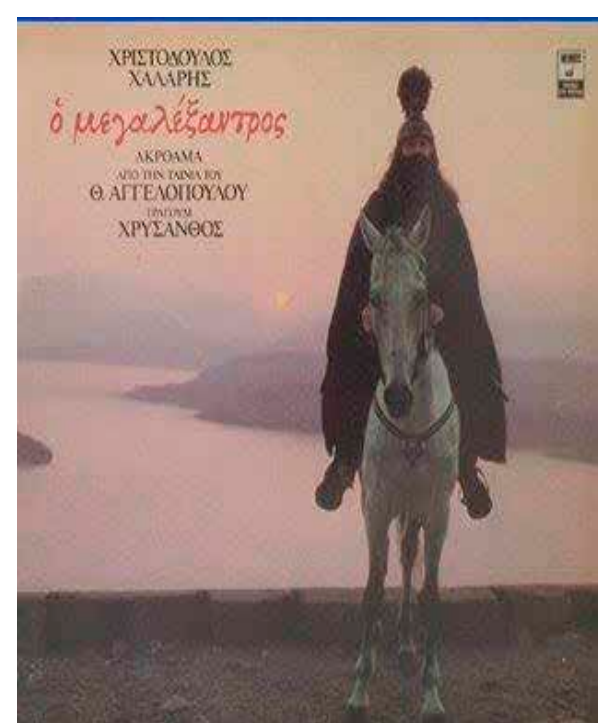

Alejandro El Grande (1980)

2 Hasta la fecha, las mejores y más acertadas reflexiones sobre la condición de Alejandro, vienen de la mano de la escritura Mary Renault, pudiendo citar M. Renault, Alejandro Magno. Barcelona: Edhasa, 2007. 
De cualquier modo, Hollywood es solamente la continuadora de una iniciativa empezada por Mauritz Stiller y su Alexander Den Store de 1917, donde el cineasta alemán dirige a Hauk Aubel, estrella escandinava del cine mudo, para encarnar otra versión libre del macedonio, salpicada por el modesto presupuesto de la cinta y lo difícil que es en la actualidad encontarla en verdadero buen estado.

Muy similar en intenciones a la de Rossen, tenemos el precedente de Sikandar, estrenada en 1941 y con Prithviraj Kapoor como el Richard Burton hindú, volviendo a presentarse la figura de Alejandro como la de un apuesto guerrero seductor de princesas extranjeras. Con alguna mención remota en otros péplums, su imagen no vuelve a ser rescatada con toda la fuerza que merece hasta que su mito evoca una poderosa imagen en el director heleno T. Angelopoulos.

Pieza clásica para el cine griego de los 80, Alejandro El Grande es una eficaz metáfora de lo efímero de la gloria, el tema que tanto obsesionó al personaje histórico, capaz de dormir en su tienda de campaña con pliegos de La Ilíada bajo su almohada y danzar en la supuesta tumba de su ilustre antepasado, Aquiles, en las ruinas de Troya.

Angelopoulos se aleja de toda esa épica y usa la imagen de Alexandrós como el complejo napoleónico de un bandido del siglo XIX, interpretado con maestría por Omero Antonutti, que llega a pensar que es su mismo ídolo re-encarnado, al estilo del cine de John Houston ${ }^{3}$.

Narrada de una forma muy particular y como si de un rompe-cabezas desordenado se tratase, es tarea complicada resumir las casi tres horas de un metraje muy extraño y personal, donde el lenguaje corporal de los actores importa mucho más que las palabras. Más terrenal que nunca, la figura de este Alejandro recuerda poderosamente el célebre poema de Ozymandias:

\section{Mi nombre es Ozymandias, rey de reyes: \\ ¡Contemplad mis obras, oh poderosos, y desesperad! \\ No queda nada a su lado. Alrededor de las ruinas \\ de ese colosal naufragio, infinitas y desnudas \\ se extienden las solitarias y llanas arenas.}

Da igual la grandeza o el botín obtenido de la empresa si al final solamente quedan ruinas y soledad. A su particular manera y mezclando épocas (son innumerables las referencias al movimiento obrero e ideologías políticas de la época por parte del artista griego), Angelopoulos propone una fusión de mitos para hacerlos más terrenales y próximos, quedando solamente del conquistador una figura que mira perdido en la ventana, quizás rememorando cuando hizo huir a Darío, Gran Rey de Persia, en la batalla de Issos. 


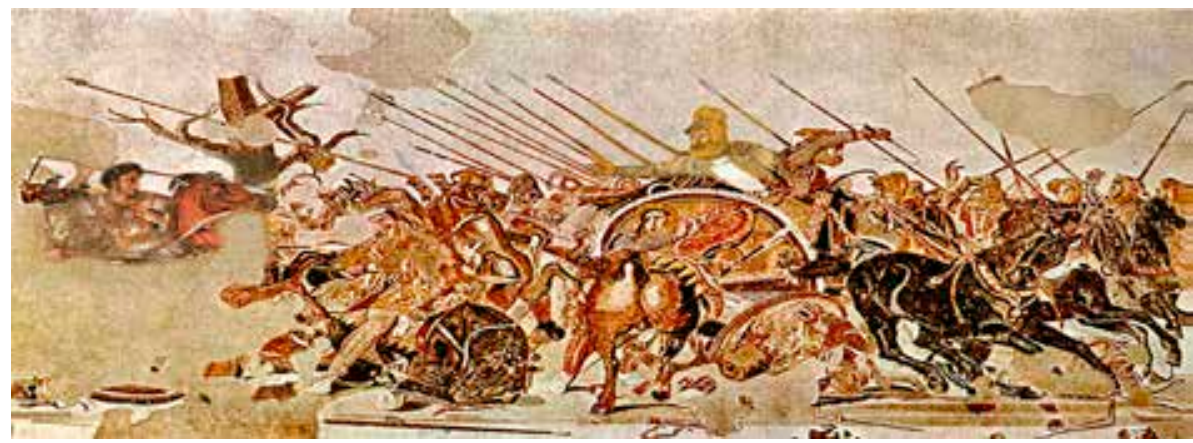

La batalla de Issos

La reflexión de la creación de esta figura por el pueblo y el papel de los bustos clásicos ensangrentados, son solamente la punta del iceberg de las paradojas del personaje, que el director tan bien intuye, mientras se permite narrar acontecimientos históricos del XIX en este curioso experimento confeccionado para el celuloide.

Alejandro fue para las propias fuentes helenas un referente y un ídolo a derribar, debido a que, tras vengar las afrentas cometidas por el Gran Rey Jerjes saqueando Grecia (siglo $\mathrm{V}$ a.C), adaptó y unificó a sus antiguos enemigos como nuevos vasallos. Esto provocó una fortísima ruptura con muchos de los miembros de su estado mayor y antiguos colaboradores. La complejidad de esta última faceta de su reinado y que tanto le desvinculaba de los proyectos de su padre, que llevaron al novelista alemán Gisbert Haefs a definirle como "El señor de las diez almas", provocó que Oliver Stone decidiese que el siglo XXI precisaba de su propia versión de la leyenda ${ }^{4}$. Convencidos por el entusiasmo del director, la Warner Bros. da luz verde a un proyecto que abarcara una co-producción entre varios países y que a la postre se convertiría en una de las películas más esperadas para la cartelera de 2005.

Ya antes de su difusión en las salas, los primeros pases generan las primeras críticas de los analistas más conservado-

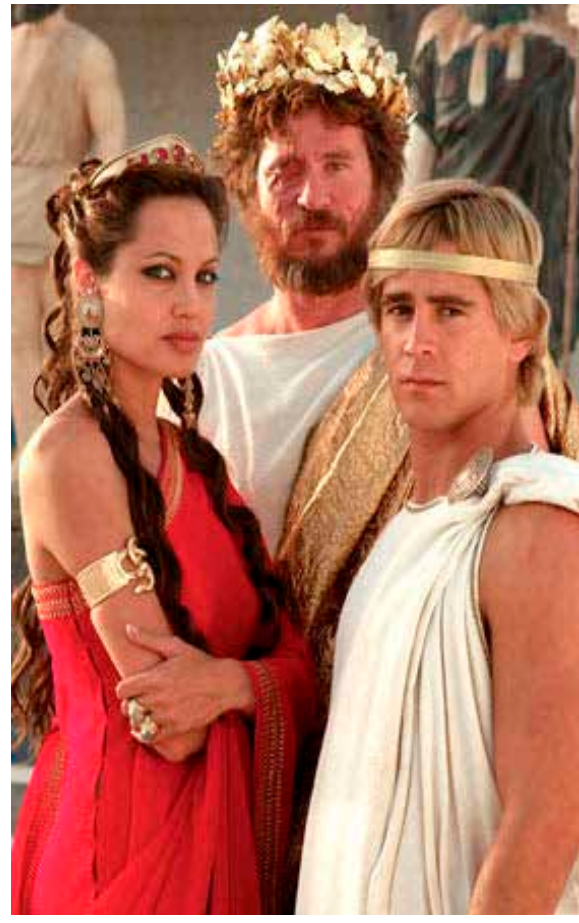

Olimpia, Filipo y su hijo, Alejandro

4 G. Haefs, , Alejandro Magno. Barcelona: Edhasa, 2005. 
res de la sociedad norteamericana. No solamente por primera vez para la gran pantalla se aborda abiertamente la homosexualidad del monarca macedonio, sino que ésta es mostrada de una forma claramente abierta, especulando incluso con que no hubiera conocido mujer hasta su matrimonio político con la persa Roxana.

También la controvertida infancia del protagonista es abordada con mayor detenimiento que en cualquier otra versión previa. Si en las anteriormente citadas se limitaban a mostrar las diferencias de carácter entre Filipo y Olimpia, Stone, en todo momento asesorado por el historiador Robin Lane Fox ${ }^{5}$, se permite profundizar mucho más en el tema.

A través de la figura del envejecido Ptolomeo I (interpretado por Anthony Hopkins), se dictan a los escribas de Alejandría algunos de los acontecimientos en los que se vio envuelto quien fuera su comandante supremo y amigo, Alejandro. La elección de este personaje como narrador es, a nuestro juicio, muy acertada, pues quizá fue el más afortunado entre los generales de un conquistador cuyo imperio se diluyó ipso facto tras su muerte. Así, Ptolomeo se erige en un juez parcialmente razonable de los hechos Alejandrinos, aparte de ser uno de los culpables del intento de divinización de su superior arguyendo filiaciones un tanto subjetivas. ${ }^{6}$

Narrada con complejidad y siempre en formato flashback, nos encontramos ante una obra irregular en cuanto a dónde se centran sus atenciones, aunque la banda sonora efectuada por Vangelis resulte sumamente sugestiva. Al margen de alguna cuestión de casting (resulta increíble concebir que Angelina Jolie pudiera ser la madre de un Colin Farrell con el que comparte generación), la dividida soledad de afectos del joven príncipe es narrada con eficacia con algún momento de gran poder visual.

Sirva como ejemplo, la escena en la que un cansado Filipo lleva a su hijo a una oscura cueva donde le muestra grabados de episodios trágicos mitológicos, enseńando a su heredero lo terrible de la envidia de los dioses. Emplear con esa contundencia la mitología, es algo clave, ya que, como hemos mencionado, Alejandro era un devoto seguidor de los grandes héroes del mundo de la Hélade ${ }^{7}$.

Val Kilmer encarna al tuerto soberano, figura controvertida y que, sin embargo, de no haber sido el progenitor de quien le eclipsó, hubiera sido considerado como el mejor estratega de la Grecia de su tiempo. En una apuesta clara por diferenciar civilizaciones, Stone y su equipo colocan actores irlandeses como macedonios puros, mientras que Alejandro y sus helenizados compañeros son, por regla general, británicos, en un curioso juego.

5 R. Lane Fox, Alejandro Magno: conquistador del mundo. Barcelona: Acantilado, 2007.

6 Una de estas inverosímiles conexiones fue la "habida" entre el faraón Nectanebo y Olimpia. Dicha falsedad es recurrente en muchos de los filmes que estamos tratando.

7 Sobre la versión de los mitos griegos en el cine, presentamos algunos de los más relevantes en A. Míguez Santa Cruz y M.R. Cańas Pelayo, "Del dios cine y otros héroes. El mito griego a 24 fotogramas por segundo", Ámbitos, no27 (2012), pp.53-65. 
La figura de Filipo era vista por Atenas como la de un bárbaro del norte sin civilizar, conquistador gracias al peso de las armas, pero muy inferior en cultura a ellos. El rey subsanó aquella carencia enviando a sus jóvenes aristócratas bajo la tutela de hombres con el prestigio del propio Aristóteles. Si bien hay paralelismos con la obra de Rossen, Stone y su equipo apuestan por una penetración en la psique de un personaje obsesionado con agradar y superar a su padre, mientras que su formidable madre le va inyectando la pretensión de un objetivo grandioso y casi divino.

Como ha sido la maldición de innumerables cineastas que se han acercado a aquella época, los 173 minutos de metraje obligan a acelerar muchos ritmos de la historia, mientras algunas figuras claves del período brillan por su ausencia (no hay mención al líder mercenario Memnón de Rodas, jefe de la resistencia persa o Demóstenes de Atenas, fundador la leyenda negra del conquistador); más que por falta de asesoramiento, por condicionantes de un contexto que exigiría una trilogía cuanto menos para poder narrarse con detalles.

Con todo, la cinta deja algún momento para el recuerdo como la peculiar manera de narrar la sangrienta batalla de Hidaspes, cuando Alejandro y su ejército mixto de griegos y persas se adentraron en la India. Narrado con efectos carmesíes con el propio monarca herido e incapaz de ver con nitidez, enseńa a la perfección las desventuras de una tropa cuyas victorias estaban siendo, paradójicamente, el germen de fortísimas tensiones y motines, ante lo inabarcable de sus dominios.

Con la más que posible excepción de la heterodoxa pero brillante visión de Angelopoulos, el Alejandro de Stone supone el acercamiento más serio a la persona por encima del personaje legendario. El film busca profundizar en sus afectos y en explicar con mayor complejidad su iniciativa de adaptación de la cultura aqueménida y la fuerte sensibilidad del soberano macedonio, no por ello perdonando algunos de los episodios más oscuros y sangrientos de su reinado.

De la boca de un Hopkins inspirado en unos monólogos que sirven de interludio entre las escenas, se aúpa el fracaso de Alejandro por encima de los éxitos de los otros protagonistas de su

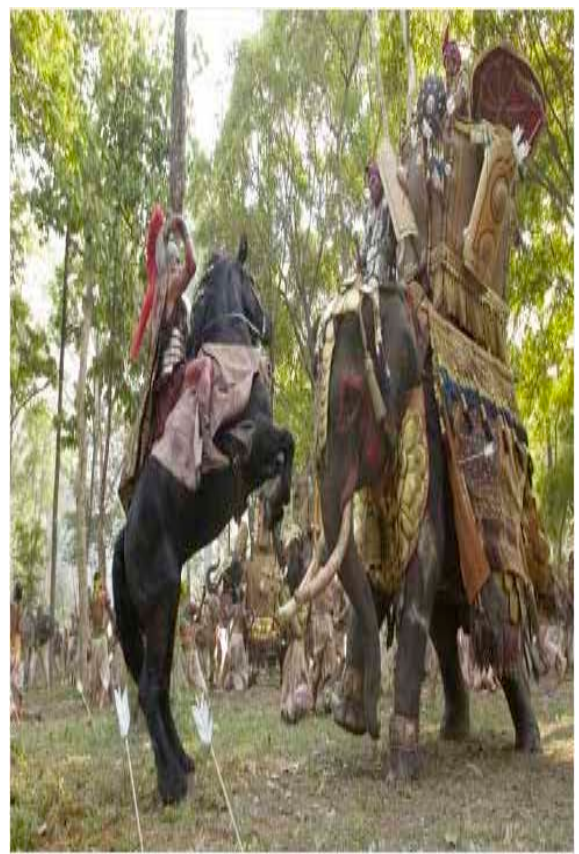

Batalla de Hidaspes 
tiempo. Desgraciadamente para los intereses de la Warner, para su elevado presupuesto y costes, la obra no recaudó lo suficiente para resultar rentable a la compañía. Desafortunadamente la espectacular ambientación de la batalla de Gaugamela, no se vio reflejada ni en crítica ni ante la taquilla, donde las expectativas no fueron las esperadas.

Pese a ello, el lirismo alcanzado con ciertas secuencias, como cuando un joven Alejandro logra convencer al salvaje caballo Bucéfalo de que las sombras que teme son rayos de Sol orquestados por Apolo, ganándose por primera vez el aplauso de su padre, consigue algunos de los mejores momentos del personaje en el medio cinematográfico.

En definitiva, aunque aún quede mucho trabajo pendiente, algunas de las facetas de las diez mil almas han ido mostrándose a lo largo de los diferentes esfuerzos de cineastas.

\section{ANÍBAL AD PORTAS: El DEMONIO CARTAGINÉS DESAPROVECHADO}

Cada pueblo de la Antigüedad reservó un lugar de preferencia a sus grandes guerreros, aupados en el Panteón particular de cada civilización. Así, Vercingetórix supone el germen fundacional de una Galia unificada para ser posteriormente transformado incluso en un símbolo del nacionalismo francés. Del mismo modo, Pericles, Leónidas o Serímamis se erigieron también en emblemas para sus pueblos, al conseguir, entre otras gestas, victorias y gloria.

De toda esa clase de figuras solamente Aníbal Barca puede presumir de haber pasado a la Historia gracias a los testimonios latinos de su gran enemiga mortal, Roma, quien, pese a odiarle, terminó adaptándole como un icono más de su

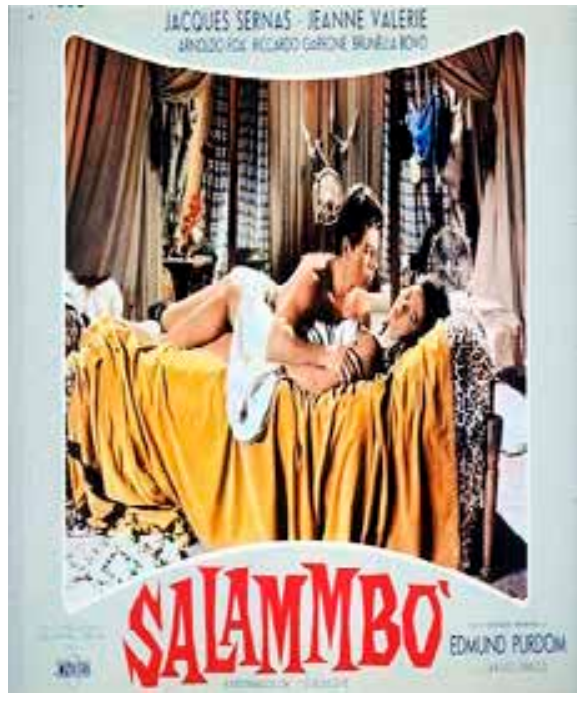

Salambó (1960) leyenda, el más temible enemigo que había conocido y que provocaba que las matronas de la urbe aún gritasen, décadas después de la muerte del cartaginés, que Hannibal ad portas!, recordatorio de lo cerca que estuvo este personaje de haber acabado con la Ciudad Eterna.

Protagonista indiscutible y principal responsable de la II Guerra Púnica (218-202 a. C.), Aníbal era el miembro de la familia Barca, una de las más poderosas de la potencia norteafricana y claros responsables de la conquista de Iberia por parte de Cartago. No obstante, en honor a la verdad, él era el heredero de un odio que se había pro- 
ducido mucho antes en el pulso por el Mediterráneo de dos potencias destinadas a chocar por la hegemonía.

A pesar de las victorias alcanzadas en el campo de batalla y de los planes ejecutados por sus hermanos, Aníbal no logró su objetivo final. Cartago, pues, fue borrada de la Historia por su ancestral enemiga, aunque la leyenda de esparcir sal sobre los despojos fue un bulo engendrado a través del mito. Las demandas de senadores como Catón se habían cumplido y la cultura cartaginesa fue condenada al ostracismo y a pasar por el filtro de lo que escribiesen sus vencedores. El cine, por supuesto, no fue una excepción y es una de las causas de la proliferación de filmes ambientados desde la óptica de quienes finalmente se hicieron la potencia del Mare Nostrum.

Afirmar eso no es óbice para reconocer que también han existido péplums que se han basado en las raíces históricas y mitológicas de Cartago. Así, adaptando la célebre novela Salambó, escrita por Flaubert y publicada en 1862, Sergio Grieco dirigió una película con el mismo título, ambientada en la terrible Guerra de los Mercenarios (241-238 a. C.), provocada cuando el gobierno púnico fue incapaz de pagar de sus arcas a sus veteranos de Sicilia.

El film tiene el mérito de presentar la figura de Amílcar (caracterizado por Riccardo Garrone), padre de Aníbal y para muchos historiadores, el pionero en los planes contra Roma que tan brillantemente ejecutó su hijo. Su figura, ecuánime con los mercenarios y heroica, contrasta con el ambicioso Narr Havas (Edmund Purdom), un oportunista aristócrata que pretende usar las negociaciones con las tropas amotinadas para reforzar su autoridad y hacerse con el poder del Consejo cartaginés en una especie de dictadura.

Igual que en el relato del gran escritor francés, el argumento tiene muy poca fiabilidad histórica, decantándose por inventar una romántica trama propia de la gran novela del XIX, entre el líder mercenario Mathos (Jacques Sernat) y la hija de Amílcar, la hermosa Salambó (Jeanne Valérie), sacerdotisa de Tanit que logra salvar a su enamorado y su delegación de una celada auspiciada por Narr Havas.

El péplum presenta algún aspecto interesante, como el hecho de resaltar que en situaciones de emergencia, se producían sacrificios humanos para aplacar a las deidades de la ciudad asediada. Si bien es cierto que la censura no permitió a Grieco llegar a los niveles de detalle de Flaubert durante los rituales en la novela, sí se deja constancia de la horrible práctica.

Como curiosidad, afirmar que la censura no se mostró contenta con algunos momentos de la joven pareja, especialmente con una Jeanne Valérie muy cómoda

8 Encontramos un excelente repaso a la cuestión y a los filmes sobre la cultura púnica, en "Delenda est Cartago: Odio Eterno a Roma-Salambó-Aníbal-Escipión El Africano-La destrucción de Corinto", en J.A. Menéndez, J.J. Alonso y E.A. Mastache, La Antigua Roma en el cine. Madrid: T\&B Editores, 2008. 


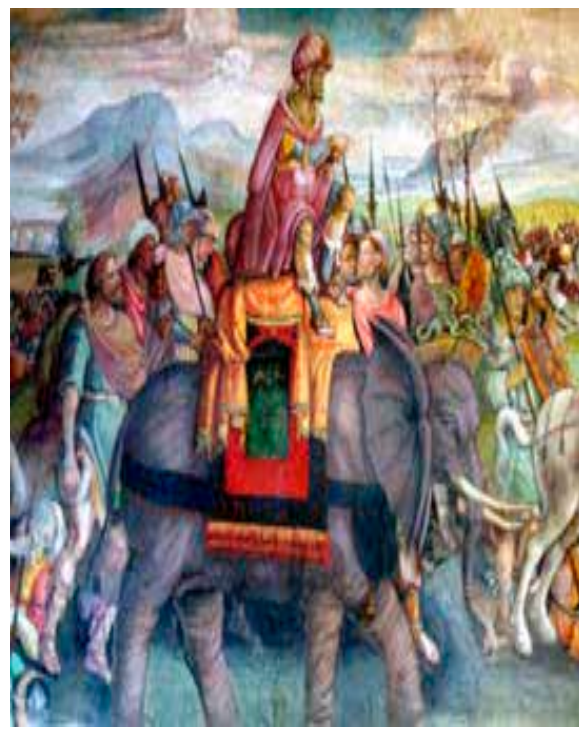

La marcha de los elefantes

como discípula de Dido, cortándose algunas escenas de la seducción entre ambos, algunas de ellas hoy afortunadamente recuperadas y re-insertadas al original. Paralelo al rodaje de este péplum, los directores Carlo Ludovico Bragaglia y Edgar G. Ulmer aprovechan el interés por el tema para rescatar precisamente a Aníbal de su olvido para el séptimo arte.

Igual que sucedía con la precedente, nos movemos en una producción italiana que sigue explotando el péplum, que se encontraba en un verdadero auge como género?. Cabiendo destacar la figura de Víctor Mature, estrella norteamericana que será el encargado de encarnar al hijo de Amílcar,

la cinta prescinde de la formación de Aníbal y sus hermanos en Iberia, iniciándose la narración cuando éste decide lanzar una gran ofensiva contra Italia a través del sorprendente paso por los Alpes (218 a.C), centrándose el metraje en los primeros años de una contienda que sorprendió absolutamente a Roma.

Osadísima maniobra que aún hoy sigue fascinando a los historiadores militares, a pesar de la dureza y los enfrentamientos con las tribus galas que custodiaban el acceso, la maniobra de Aníbal trastocó todos los planes de presión del Senado romano y, a diferencia de previos choques entre ambas civilizaciones, fue la primera vez que Italia sufrió en sus carnes la pugna.

Como le sucedió durante su encarnación del personaje bíblico de Sansón ${ }^{10}$, los recelos de Mature ante las escenas de riesgo provocaron visibles falsificaciones de los supuestos elefantes púnicos que los cartagineses tienen que azuzar para trasladarlos a la tierra de sus enemigos. Más que probablemente influenciado por el precedente de Pirro de Epiro, Aníbal confiaba en el pánico que estos animales provocaban en las compactas legiones romanas.

Superadas las dificultades logísticas, una vez en Italia, Aníbal, mediante hábiles pactos, va avanzando de victoria en victoria. Buscando aderezar la trama con un componente romántico, los guionistas del péplum se inventan una ficticia relación amorosa entre el "demonio púnico" y una sobrina del dictador Quinto

9 Entre otros, destacar J. Solomon, Péplum: El mundo antiguo en el cine. Madrid: Alianza Editorial, 2002.

10 Sansón y Dalila (1949). 


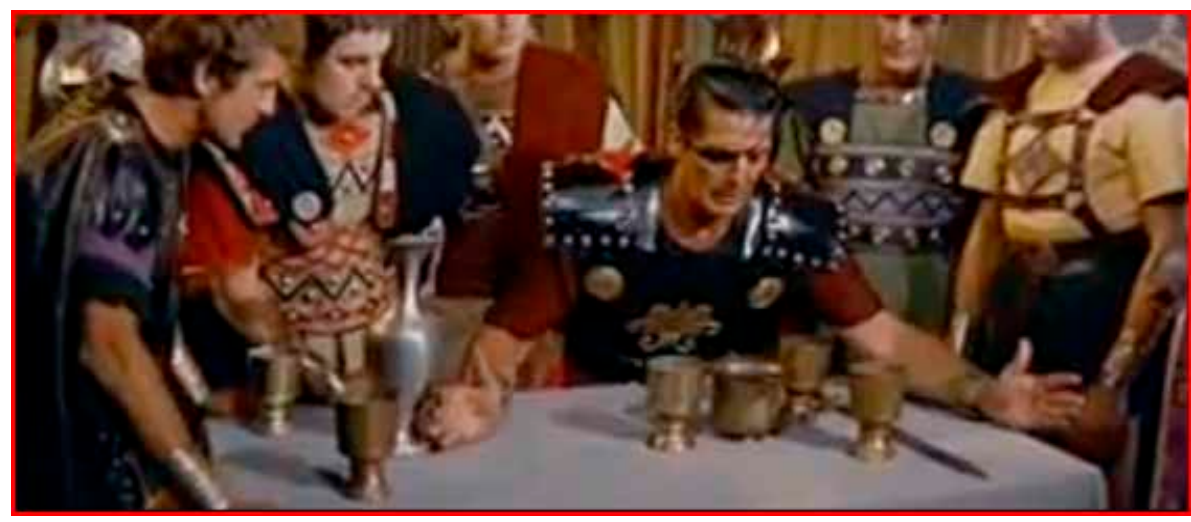

Aníbal explicando a su estado mayor la táctica envolvente de Cannas

Fabio Máximo, que abandonará sus votos para las Vestales cuando caiga prisionera del gran enemigo de su pueblo ${ }^{11}$.

Fabio es interpretado por el actor italiano Gabriele Ferzetti, presentado como el único patricio consciente de la verdadera amenaza que han despertado sus conciudadanos al ofender el orgullo de una Cartago adormecida por su anterior derrota.

Tras las espectaculares victorias de Aníbal en las batallas de Trebia, Tesino y Trasímeno, obviamente, la gran contienda que se refleja en la película es la de Cannas (216 a.C.), donde el cartaginés aplastó a dos ejércitos consulares y sus aliados de una forma brutal en una de las tácticas más resonantes de todos los tiempos. A pesar de no contar con muchos recursos técnicos, la película tiene el acierto de explicar de una manera clara la treta de Aníbal a través de su reunión con sus hermanos y generales en su tienda de mando.

En definitiva, un péplum que se vio limitado por la magnitud, como sucedía con Alejandro, de las vivencias históricas del personaje. Ni tan siquiera la derrota de Aníbal o su exilio en Asia pudieron ser tratados convenientemente, sino a través de un epílogo a modo de resumen, muy al estilo del adoptado por Henry Hathaway para el desenlace biográfico de otro enorme estratega militar, Erwin Rommel en El zorro del desierto (1951).

Tanto Salambó como Annibale marcan la tendencia de Cartago en llamas (1960), otro exponente de la efervescencia del mundo púnico en el péplum, narrándose en este caso, obviamente si atendemos al título, la destrucción de la capital cartaginesa ante las tropas de Escipión Emiliano, en la última de las contiendas de estas dos potencias. Teniendo en cuenta que Emiliano era el des-

11 Jugada clásica de los péplums, como ya hemos visto en Salambó, crear un romance entre personajes de dos mundos, ante la oposición de todo el sistema de la época. Este añadido literario está ejemplarmente analizado en http://www.publicacions.ub.es/bibliotecadigital/cinema/ filmhistoria/2001/oscarlapena1.htm, por cuenta de Óscar de La Peńa, uno de los nuevos y más interesantes investigadores en el tema. 
cendiente de Publio Cornelio Escipión El Africano, el primer general romano capaz de derrotar con claridad en combate a Aníbal, daba la sensación de que se cerraba un círculo con esta particular trilogía de relatos inspirados en los súbditos de Baal.

Resulta muy curioso que en ninguna de ellas, aunque se mencione, se use la batalla de Zama (202 a.C.), llanura donde Aníbal y Escipión tuvieron el enfrentamiento definitivo que marcó el inicio del ocaso del gran estratega cartaginés. Si bien, hasta la fecha, ningún realizador ha mostrado interés en retomar los sucesos de esa pugna, la figura de la Némesis del Bárquida sí ha sido tratado en varios filmes, donde, pese a no aparecer físicamente, el espectro del vencedor de Cannas es omnipresente.

Así, encontramos en 1937 la película Escipión El Africano, que narra las victorias de este aristócrata romano, cuyo padre y tío fallecieron combatiendo a los hermanos de Aníbal en Iberia. Rodada por Carmile Gallone en pleno auge del fascismo del Duce Mussolini, la cinta es un libreto propagandístico que pretendía exaltar el más primitivo nacionalismo; además, el propio hijo del dictador italiano, Vittorio, buscaba que se estableciesen paralelismos entre las operaciones en el norte de África del comandante con las campañas italianas en Etiopía, por aquellos años en un loco sueño colonial.

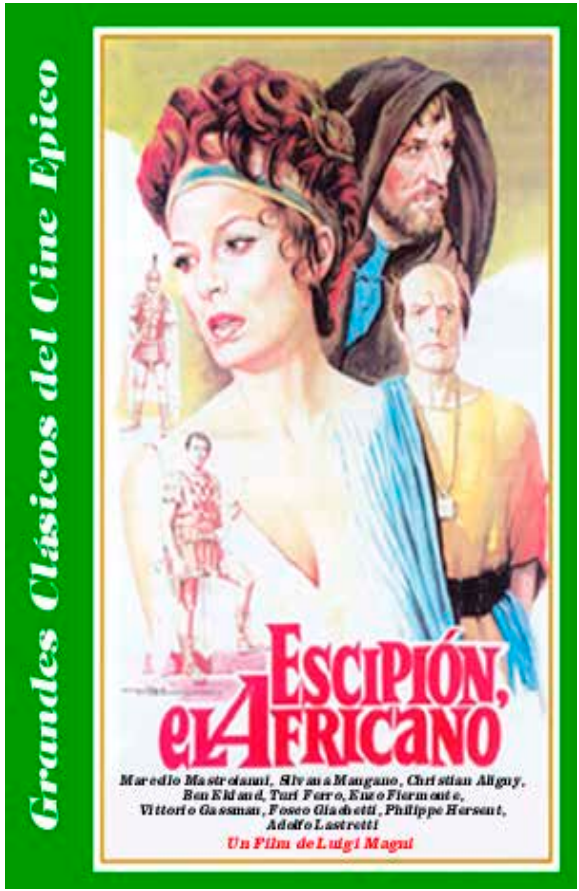

Escipión El Africano

La más recordada de todas las producciones italianas que han abordado a su héroe, es, indudablemente, Scipione detto anche l'Africane (1971). Aquí, el director, Luigi Magni, nos muestra un héroe más cercano al declive que representa la madurez que de sus épicas gestas de juventud. Para entonces, el héroe se ha convertido en un recuerdo dudoso, icono de una de las situaciones más extremas vividas por la República. Para colmo, las envidias que aún despertaba entre los senadores originaron conjuras para derrocarle y apartarle del poder. El peor de todos esos oponentes es Marco Porcio Catón (interpretado por Vittorio Gasman), quien encuentra la oportunidad soñada cuando el hermano del héroe no puede justificar ciertas cantidades de oro recibidas por un rey oriental vasallo de Roma. A través de Lucio Escipión (Ruggero 
Mastroianni), Catón y los suyos buscan salpicar y derribar de su pedestal a su afamado pariente.

Marcello Mastroianni es el encargado de encarnar al veterano, orgulloso y cansado héroe, que tiene problemas hasta para mantener la armonía conyugal con su esposa (Silvana Mangano). Lejos de la solemnidad que pretende el péplum, esta obra es una tragicomedia con muchos (e intencionados) anacronismos en sus diálogos y donde las hipérboles son constantes. De un fuerte cinismo, el film usa a los poco morales senadores romanos como metáfora del propio sistema político de la Italia de su tiempo.

A pesar del desenfado de toda la narración, la conclusión general es terrible. Sin la presencia de un Aníbal que amedrente a toda la urbe escondida en sus murallas, Escipión pierde la razón de ser y se convierte en una majestuosa presencia que se hace molesta y que, finalmente, como el propio hijo de Amílcar, debe inmolarse para que su pueblo siga, quedando él como un vestigio mítico, pero de un lejano pasado.

Así permanecen estas dos vidas paralelas y tan ligadas, cuanto menos, hasta que vuelvan a suscitar la atención de un cineasta capaz de juntar ambas figuras en la gran pantalla.

\section{El Mesías Pagano: Espartaco y Stanley Kubrick}

"En el último siglo antes de la era cristiana, Roma era el centro del mundo civilizado [...] Por aquel entonces, y en la conquistada provincia de Tracia, una de las esclavas aumentó la riqueza de su amo, dando lugar a un hijo al que llamó Espartaco. Antes de que hubiera cumplido los 13 años, fue vendido para trabajar en las minas [...] Bajo el látigo y el Sol, Espartaco creció y se hizo hombre, soñando con la abolición de la esclavitud. Los historiadores de la Roma pagana registraron el fracaso de su sueño y el exterminio de su cuerpo y esperanzas [...] El sacrificio de Espartaco se convirtió en el triunfo de la Humanidad".

Así comienza la narración con voz en off de la película Espartaco (1960), presentando la figura del gladiador rebelde que desafió el poder establecido de las legiones romanas (73-71 a.C). Revueltas de esclavos ya habían sido conocidas por el Senado durante esa misma centuria, especialmente en los campos de Sicilia, pero el hecho de ver amenazada la propia capital y la dimensión sin precedentes que alcanzó, sirvió para que su caudillo alcanzase la inmortalidad en las fuentes clásicas (Plutarco, Apiano, Floro...).

Dirigida por un cineasta tan brillante como heterodoxo, Stanley Kubrick, la producción del film supuso un viaje verdaderamente accidentado donde incluso hubo cambios inesperados de última hora; así, Anthony Mann (a quien corres- 
ponden las escenas del principio en la escuela de gladiadores de Capua), fue sustituido por Kubrick debido a sus discrepancias con Kirk Douglas, actor protagonista y productor de la misma.

No parece el presente artículo el lugar más adecuado para hablar de los sinsabores de un rodaje tremendamente polémico ${ }^{12}$, aunque baste decir que estamos ante una verdadera obra pionera dentro del género, con unas características propias y singulares que, unidas a las muchas lecturas que ofrece la misma, la hacen eterno objeto de debate, aderezado todo por las fuertes personalidades que participaron en el proyecto ${ }^{13}$.

Espartaco puede interpretarse como la biografía idealizada para la gran pantalla del gladiador y su causa rebelde, desde su alzamiento contra el lanista Batiato (interpretado por Peter Ustinov); con todo, es también un reflejo de las maniobras senatoriales de Marco Licinio Craso (Laurence Olivier), para aprovechar el pánico de la ciudad con la revuelta para aumentar su posición y eliminar a sus enemigos políticos, encabezados por el senador Graco ${ }^{14}$ (Charles Laughton). Pese a ello, el guión del film aporta una dimensión que va más allá de Clío, casi espiritual.

El discurso inicial de nuestro narrador omnisciente ya pone de relieve la aparente ausencia de elementos religiosos en la historia. Nos hallamos antes de la aparición del cristianismo y en época de la República Tardía Romana, casi en vísperas de que Cneo Pompeyo, Julio César y el propio Craso, asienten con su Primer Triunvirato, las bases del Imperio. Estamos lo suficientemente alejados del Antiguo Testamento y de los martirios cristianos en El Coliseo como para pensar en el elemento mesiánico típico de muchas de estas producciones, pero no es así, en lo absoluto.

La palabra sacrificio no es baladí en la introducción. Desde el principio, se quiere introducir en los espectadores la fuerza del nombre de Espartaco, algo nada extrańo, teniendo en cuenta que varias organizaciones revolucionarias del siglo XIX lo han adoptado como patrón, mientras que autores como Marx o Rosa Luxemburgo le han mostrado fuertes simpatías, mientras la iconografía soviética lo alzó como estandarte. No importan nada las licencias con respecto a su origen ${ }^{15}$

12 Una buena aproximación al tema lo encontramos en M.M. Winkler, Spartacus: Film and History. Oxford: Blackwell Publishing, 2007.

13 "Morituri te saludant: Un hombre de izquierdas (y su hijo): Espartaco-El hijo de Espartaco", en J.A. Menéndez, E. A. Mastache y J.J. Alonso, La antigua Roma en el cine, Madrid: T\&B Editores, 2008, pp.76-107.

14 Aunque el apellido Graco debe interpretarse como una clara reminiscencia a los dos famosos tribunos de la plebe, Cayo y Tiberio, se trata de un personaje totalmente ficticio y sin vinculación con los mismos.

15Como varios especialistas han destacado, la denominación en las fuentes latinas de "tracio", no implicaría un origen por parte de Espartaco en dicha región, sino que simplemente pudiera hacer referencia al tipo de arma con la que estaba especializado en la arena. Entre los muchos trabajos existentes, podríamos destacar, por reciente, el estudio de B. Strauss, La guerra de Espartaco. 
y sí cómo el hombre trasciende hasta ser un símbolo. De hecho, es una de las ideas centrales del drama planteado por Kubrick, a medida que avanza con su ejército de esclavos.

Aunque no hay ningún elemento sobrenatural en el personaje interpretado por Douglas ("Soy hijo y nieto de esclavos" llega a confesar cuando los aduladores quieren ennoblecerle), sus características y virtudes, como nos muestra la narración inicial, parecen escapar a las de un simple mortal. A medida que evoluciona, tanto en su compasión con los compañeros de la mina en Tracia o en los vínculos de sus camaradas (aún a riesgo de la propia vida en la arena) con sus colegas gla-

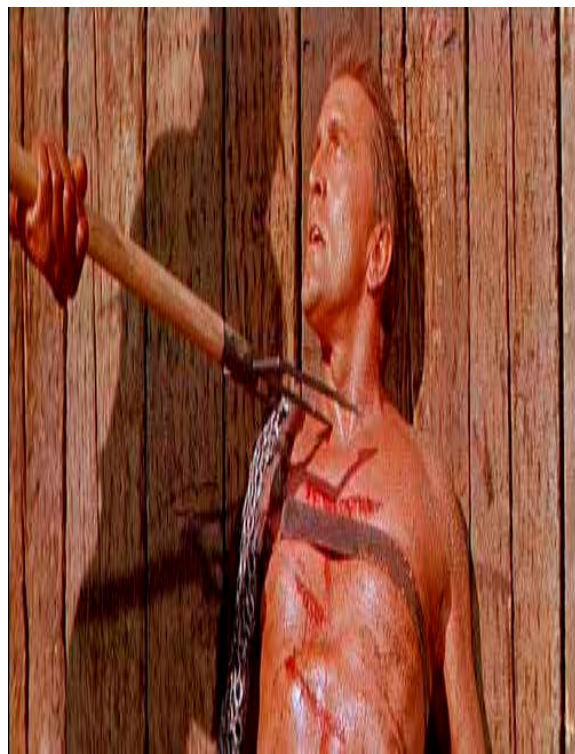

Espartaco en la arena diadores, Espartaco se va erigiendo en un líder redentor, una guía para rebelarse ante una sociedad injusta ${ }^{16}$.

Así, el guión de esta súper-producción de la época y de gran metraje, está revestida de un fuerte peso moral. No se puede olvidar que la trama está basada en la novela de Howard Fast ${ }^{17}$, quien dio un trasfondo solidario y que los comités de vigilancia norteamericanos juzgaron como sospechosos de comunismo. La participación del gran guionista Dalton Trumbo, acusado de tener un pensamiento de extrema izquierda, solamente aumento la polémica alrededor del rodaje.

Tanto Espartaco como su "pueblo" son presentados desde un punto de vista utópico, una sociedad perfecta y heterogénea. Incluso los más desfavorecidos son tratados de una forma humanitaria. Al igual que Fast, Trumbo omite las tropelías y los saqueos inevitables de toda guerra, para presentar siempre a unos gladiadores muy humanos. Solamente hay un momento de duda cuando Crixo, lugarteniente

Barcelona:Edhasa, 2010.

16 Particularmente encuentra su caída de Damasco cuando, uno de sus compañeros, Draba, le perdona la vida tras un combate realizado bajo el calor de Capua para solaz de adineradas patricias romanas, una de ellas esposa de Craso. Es muy curioso que Draba sea un personaje de color (interpretado por Woody Strode) y que sacrifique su vida por quien luego redimirá a todos sus compañeros de combate. Varios analistas insisten aquí en el auge del movimiento por los derechos raciales y figuras como Luther King, algo que no es nada descabellado, atendiendo a la personalidad de Trumbo y Fast.

17 Innumerables, la edición que hemos manejado para este artículo, H. Fast., Espartaco, Madrid: Alianza Editorial, 2005. 
galo, es el cabecilla de una exhibición en la arena donde los alzados quieren ver morir a dos ricos terratenientes romanos. Por supuesto, Espartaco intenta (y consigue) convencerles de desistir en dicha actitud.

En vísperas de importantes batallas y decisiones, Espartaco, al igual que un patriarca de Israel o un héroe mítico heleno, se dirige a su pueblo en Asamblea, siendo su voz siempre oída y respetada. Sus visionarios sueños de abolición de la esclavitud e incluso su agudeza política (intuye que Craso quiere usarlos como caballo de Troya para sus propios intereses), parecen por encima del propio personaje y sus condicionantes.

El lado más oscuro de Espartaco y sus posibles flaquezas quedan oscurecidos, más aún ante el brillo de su relación amorosa con Varinia (Jean Simmons), otra antigua esclava de Batiato con la que terminará teniendo un hijo. Todo en Espartaco prevalece como un guía espiritual de su comunidad, mientras que Roma es presentada como una cueva de alimañas y ambiciosos oportunistas, que prefieren imponer el peso de sus legionarios a cualquier otra solución.

Todo ello queda muy reflejado en las facciones de Graco y Craso, ya citados. El primero es un hombre irónico que incluso confiesa a sus jóvenes protegidos, que si en el Foro hace plegarias a todos los dioses, en privado no lo hace con ninguno. Inteligente, supone una mezcla de epicúreo (por su sed por la vida) y estoico (su resignación ante la Roma de las proscripciones que Craso va a ir generando, un clarísimo y nada disimulado dardo de Trumbo al comité). Él intuye acertadamente que Espartaco no es el mal de su ciudad, sino lo que puede obtener Craso de esa amenaza.

Por el contrario, su conciudadano, es todo lo opuesto. Es un senador activo y que cree en los valores atávicos del pasado de su ciudad, que sueńa con liderarla, aunque tema deshonrarse cruzando el límite sagrado (pomerium) como hizo Lucio Cornelio Sila ${ }^{18}$. Pese a tener la fuerza de las armas y de su riqueza, Craso busca lograr el poder a través del mando de esas operaciones. "No voy buscando la gloria. Voy en busca de Espartaco", llegará a bramar cuando logra su ansiado mando.

La obsesión de vidas paralelas que empieza a surgir entre el patricio romano y su enemigo es tan progresiva como absorbente. En un principio Craso ni siquiera recuerda haberle visto combatir para él en Capua, pero, posteriormente, terminará atraído por Antonino (Tony Curtis) y Varinia, quienes, en algún momento, estarán a su servicio como esclavos. El nombre de Espartaco (es muy importante la fuerza de lo nominal aquí) empieza a perturbar al personaje hasta lograr incluso hacerle perder momentáneamente el juicio.

18 Comprensible a nivel dramático (Craso necesita a los gladiadores alzados como pretexto), lo cierto es que estamos ante una licencia histórica muy considerable del argumento. Lucio Cornelio Sila (138-78 a.C.) marchó hasta en dos ocasiones contra su ciudad, siendo ayudado en la segunda de ellas por Marco Licinio Craso, siguiendo la política de sus parientes, siempre partidarios a la causa del que fuera dictador de Roma. 
Nos referimos a una de las escenas más peculiares de la película. Gracias a su poderoso contingente y las ayudas de los generales Lúculo y Pompeyo, Craso logra una victoria definitiva y trata de corromper a los supervivientes para que delaten a su líder o identifiquen su cadáver. Bajo el grito de "YYo soy Espartaco!", llega un momento muy emotivo que no ocurrió para la Historia, pero es una metáfora excelente de la identificación que ha logrado este mesías pagano con su gente. Aún a día de hoy, sigue siendo una escena enorme influencia y muchas veces emulada.

Tramando una ingeniosa y cruel advertencia para futuros aspirantes a rebeldes, Craso ordena que los prisioneros vayan siendo crucificados por las vías camino de la urbe. Con premonición del destino, deja a Antonino, a quien ya conoce, junto con el hombre que intuye, como efectivamente es, que se trata de Espartaco. Amparándose en su linaje y rango, Craso se presenta ante él una noche, pero a pesar de tenerle cubierto de cadenas, el adinerado patricio termina lanzando un grito de pánico y una bofetada patética ante su indefenso rehén, mientras Espartaco es capaz de sostenerle la mirada sin ningún problema.

Pese a su falta de dudas en el campo de batalla de abatirle, Espartaco, como confiesa el propio Craso en sus diálogos, teme haber perdido ante alguien que, a fin de cuentas, es muy semejante a un dios. La imagen de su crucifixión no deja de ser una clarísima herencia judeocristiana, la redención máxima alcanzada a través de un sacrificio inhumano, con la esperanza de la perpetuación y redención ${ }^{19}$.

Como vemos, incluso en una cinta que se sirve del pasado para hacer crítica social y política de su tiempo, encontramos fuertes rasgos y códigos religiosos en muchos de sus momentos, aunque tengan un objetivo claramente distinto al de las súper-producciones bíblicas o las recreaciones de los mitos. Espartaco, a diferencia de figuras de la Antigüedad, tuvo la fortuna de caer en las manos de uno de los más hábiles cineastas de su tiempo, junto con un fuerte guión y excelente reparto.

La visión de Kubrick y su equipo no es la única, aunque sí la más rememorada por su indudable calidad. Así, encontramos un precedente en Espartaco (1913), película italiana que también toma la figura del rebelde, aunque en este caso, bajo la dirección de Giovanni Enrico Vidali. Basándose en un relato de Raffaello Giovagnoli, convierte al tracio en un paladín novelesco.

También relativamente desapercibida, será Spartacus (2004), emitida directamente para televisión, obra de Robert Dornhelm y con Goran Visnjic como el tracio. Aunque presenta algún mérito como mostrar más disidencias entre los rebeldes que la idílica fábula de Fast, a pesar de ser más moderna, sus secuencias de

19 En este caso, sin embargo, siguiendo con la tónica de la obra, la explicación es más terrenal, pero para nada carente de paralelismo religioso. Sobornado por Graco, Batiatio rapta a Varinia de la casa de Craso junto con su hijo y logra sacarlos camino de Aquitania. Antes de partir, logran ver a Espartaco, ya en la cruz, pero con las fuerzas suficientes para ver a la mujer que ama y su descendencia, que han logrado la libertad. 


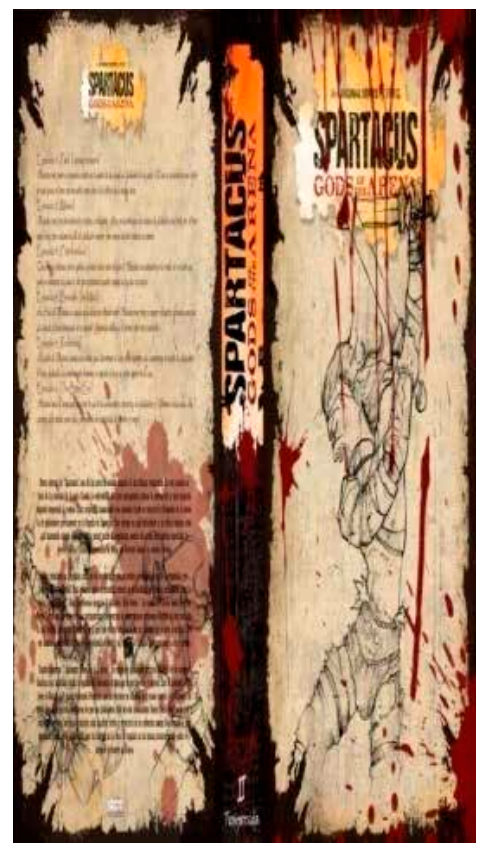

Dioses de la arena

batallas palidecen ante la imaginación de Kubrick (por ejemplo, las ruedas en llamas) e intenta emular a la exitosa Gladiator (2000).

Mención especial merece la apuesta de la cadena de cable norteamericana Starz, quien desde 2010 dio luz verde a una serie que se está encargando de presentar para la pequeńa pantalla al personaje.

Con una estética muy cercana al formato del cómic impulsado por Frank Miller en 300 y adoptado por Zack Snyder para la versión cinematográfica del mismo, Spartacus: Blood and sand es un relato hiperbólico que en sus coreografías de combates de gladiadores apuesta siempre por la exageración y una facilidad para forzar el contenido de violencia y sexualidad. De la misma forma, sería de justicia añadir que presenta una renovación de la figura atormentada del gladiador del péplum clásico, mostrándolos más como (en algunos casos) verdaderas estrellas desbocadas de rápidos ascensos y caídas, capaces incluso de disfrutar de su profesión . Los grabados de Pompeya de admiradoras de los discípulos de lanistas y glosas de poetas de sus victorias, encajan bastante bien (dentro de sus licencias) con la forma de sus guionistas de presentar la Casa de Batiato.

La trágica enfermedad de su actor protagonista, Andy Whitfield, provocó la mini-serie Dioses de la arena, donde se exploraban los orígenes del resto de personajes con la misma estética de su predecesora y esa perturbadora capacidad de captar, a su peculiar manera, la esencia de aquella terrible realidad ${ }^{20}$.

\section{Cleopatra: LA Leyenda de unOS OJOS Y UNA NARIZ}

"Si la nariz de Cleopatra hubiera sido más corta, toda la faz del mundo hubiera cambiado". Esta frase, acuñada por Blaise Pascal, sigue aún a día de hoy siendo utilizada en infinidad de ocasiones para reflejar cómo el más mínimo detalle puede desencadenar acontecimientos inimaginables. La protagonista de la cita,

20 Para el recuerdo algunas figuras como la de Gannicus en la pre-cuela, el primer gladiador estrella de Batiato. Su imagen ebria y cerca del foso de la Escuela, en vísperas del gran combate para alcanzar su fama, es un excelente trazado para mostrar lo efímero de estos dioses de la arena. 
no es otra que Cleopatra VII (69-30 a.C), una de las hijas de Ptolomeo Auletes, duodécimo faraón con ese nombre.

A pesar de haber regido en un Egipto decadente y que estaba ya muy cercano a la órbita de Roma, el mero nombre de esta monarca evoca en el imaginario popular la visión de las pirámides, el esplendor del Nilo y una cultura milenaria. Con su suicidio antes de la conquista final de Augusto tras la batalla de Actium (31 a.C.), podría decirse que se sellaba un camino que había comenzado Ptolomeo I, el mítico general de Alejandro Magno, ya citado (anteriormente), y fundador de una dinastía de la que ella era el último eslabón.

Enfrentada, como solía suceder en su dinastía, a sus hermanos por el trono en sangrientas conjuras palaciegas, donde los recursos y el veneno se ponían a prueba, Cleopatra estaba exiliada con una escasa tropa mercenaria en Siria, el destino de Cleopatra cambia cuando se presenta ante Julio César durante la guerra de Alejandría (48 a.C.). Se inicia así una alianza que se traducirá en uno de las relaciones más famosa de la Historia y que solamente acrecentó la leyenda de ella como seductora cuando, tras el asesinato de César, terminó haciéndose la amante de uno de sus sucesores, Marco Antonio.

Escritores como Terenci Moix sacaron provecho de la imagen de la eterna seductora (No digas que fue un sueño: Marco Antonio y Cleopatra, 1968), creando una figura mítica y muy reconocible para todos.

Desafortunadamente, en algunos de esos casos, la visión de la re-encarnación de Isis no dejaba de ser el reclamo erótico de un texto o cuadro, lo cual no dejaba de resultar curioso siendo una de las pocas figuras femeninas a la que las fuentes antiguas han prestado una detenida atención.

A lo largo de sus diferentes encarnaciones cinematográficas, el cine se ha encargado de mostrar muy diferentes Cleopatras que obedecían a la necesidad del momento. Intentemos analizar algunas de las más representativas y otras menos conocidas, pero muy innovadoras.

La primera pieza de obligada referencia al trabajo de Cecil B. Demille, famoso realizador que se jactaba de que con un par de páginas de la Biblia era capaz de sacar una gran súper-producción. Estrenada en 1934, su Cleopatra supone dar el protagonismo a una Clau-

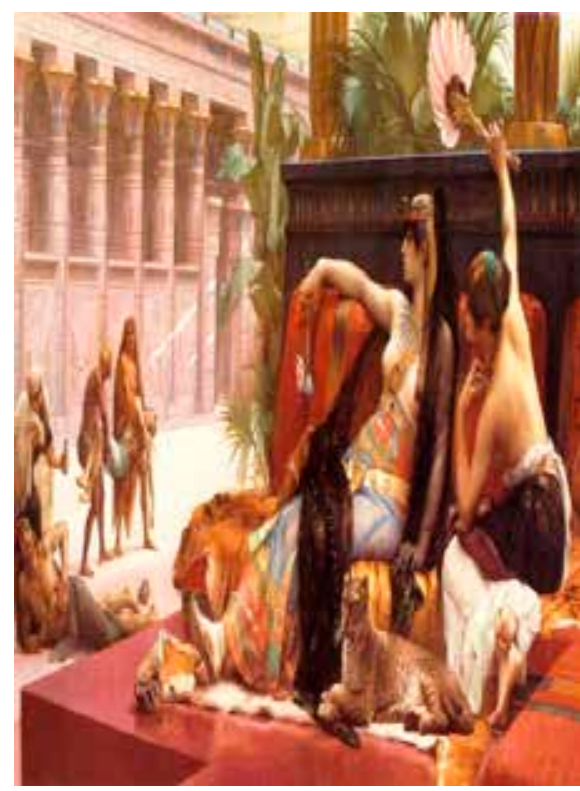

La reina Cleopatra 


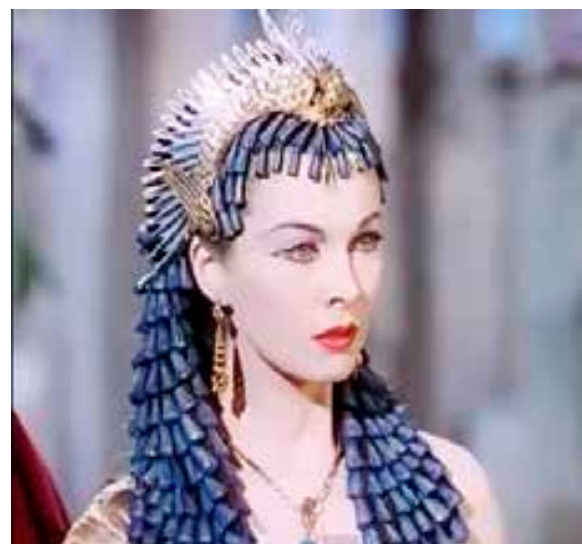

Vivien Leigh

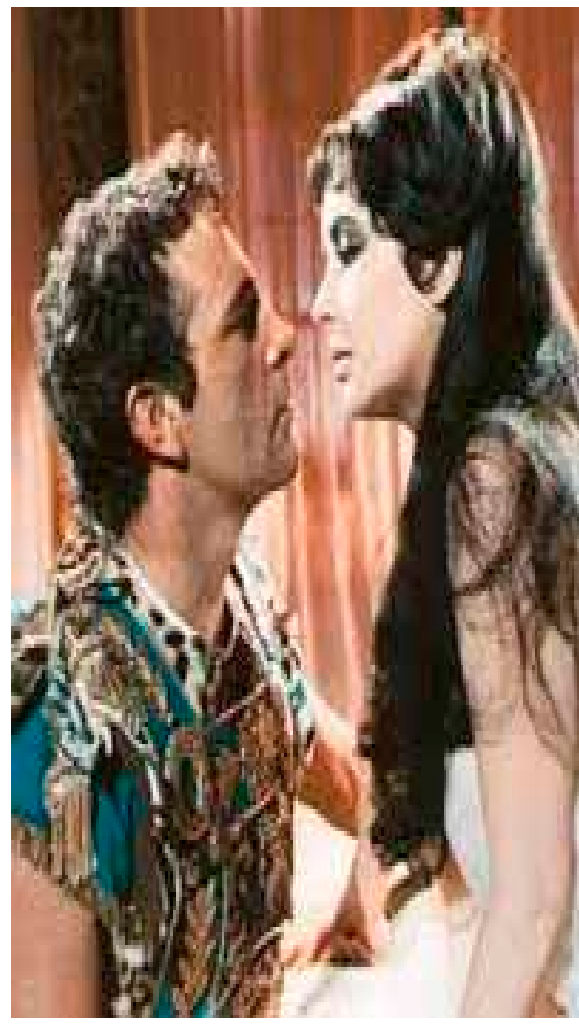

Marco Antonio y Cleopatra dette Colbert que logra seducir a los dos hombres más poderosos del Imperio Romano $^{21}$. Con sugestivas imágenes de un Egipto idílico, Demille logra crear una buena cinta pero que no profundiza excesivamente en la psique de unos personajes archi-conocidos y que, con la excepción de la evolución de Colbert, apenas van teniendo variaciones.

Más personal es la visión que arrastra el film británico de George Bernard Shaw, adaptando la pieza teatral del mismo autor, bajo el elocuente título de César y Cleopatra (1945). Bebiendo mucho de la estética original teatral, el famoso romance queda desvirtuado, al convertir el vínculo entre Cleopatra y César en una relación casi paternofilial, terminando unidos por una sincera amistad.

Claude Rains encarna a un César más envejecido que en otras versiones, un aparentemente despistado extranjero en una Corte que no entiende, pero en realidad, una astuta mente que evalúa cómo mejorar la situación del reino colocando a una persona digna en el trono. Vivien Leigh muestra a una Cleopatra adolescente que va madurando a medida que aprende de su inesperado mentor, a quien en ocasiones ataca ("César dice que quiere a todo el mundo... pero no quiera a nadie") y en otras idolatra.

Importa poco el rigor en este curioso cuento de kilométricos diálogos y rodado casi exclusivamente en el decorado de palacio, pero, que cuanto

21 La personalidad política de Cleopatra está en constante revisión, por reciente, podemos citar el estudio de A. Goldsworthy, Antonio y Cleopatra, Madrid: La Esfera de los Libros, 2011. 
menos, es una apuesta interesante por la originalidad al quitar por primera vez el elemento de tensión sexual entre el romano y la egipcia, basándose principalmente en el carisma de la pareja protagonista.

Alejándose de esta modesta pero interesante producción británica, la Fox decide rescatar la majestuosidad de antiguos proyectos como el ya citado DeMille, para traer con todo el aparato ornamental la figura más reconocible del mundo clásico egipcio. Es el germen de un proyecto complicado y que no culmina hasta 1963.

De esta forma surge una nueva Cleopatra llega a las pantallas, aunque en esta ocasión, pese a la inversión, supondrá un inesperado descalabro en taquilla.

Buscando una pareja protagonista fácilmente reconocible, el casting apuesta por reunir la química en pantalla de dos de los actores más famosos del momento en Hollywood, Elizabeth Taylor y Richard Burton.

Desde el primer momento, queda claro que la gran estrella norteamericana no da precisamente el perfil de bronceada elegida del dios $\mathrm{Ra}$, aunque algún rasgo de cosecha propia como su fascinante mirada pueden interpretarse como don compartido con la reina de Alejandría. También se realizan dispendios para lograr que César sea interpretado por Rex Harrison, quien rodea de un aura regia a su
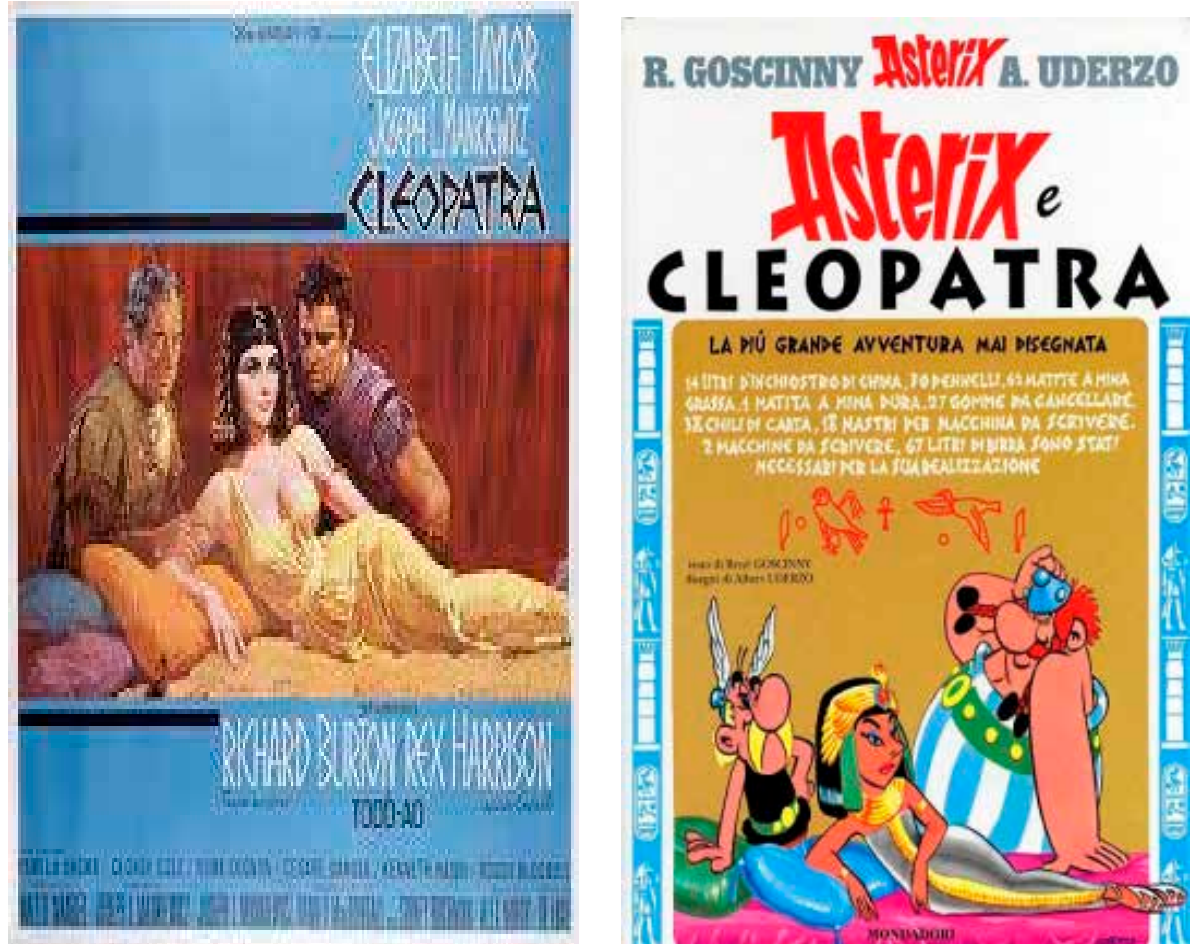

Carteles paralelos: Cleopatra en Hollywood y Astérix 


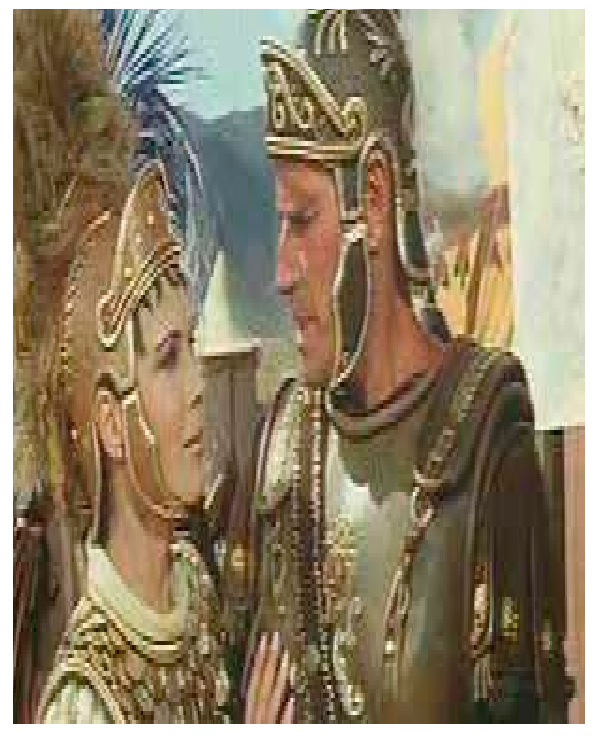

Marco Antonio y Cleopatra

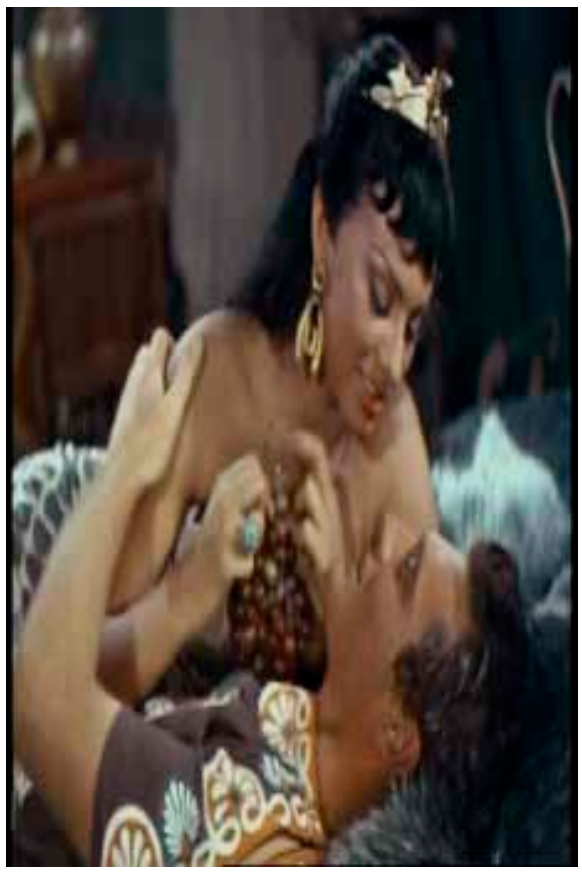

Las noches de Cleopatra personaje, acentuándose en este film la fuerte diferencia de edad entre los dos amantes y evidenciando como Cesarión surge fruto de esta relación.

Con una gran cantidad de problemas de rodaje y dificultades durante el proceso de creación, Cleopatra escapa en sus pretensiones al péplum, aunque tampoco llega a alcanzar la independencia artística del Espartaco de $\mathrm{Ku}$ brick. A buen seguro, la falta no radica en el director escogido, nada menos que Joseph L. Mankiewicz, quien no solamente se encarga de la realización, sino que participa activamente en un guión que pasa por varias manos (Ranal MacDougall, Sidney Buchman y el propio Mankiewicz).

Narrada con la majestuosidad de producciones tales como Ben-Hur o Los diez mandamientos, la película arranca con el desembarco de César en Alejandría a la búsqueda de su enemigo Pompeyo, que ha huido tras ser derrotado por éste en Farsalia (48 a.C.), buscando amparo en sus antiguos aliados egipcios, solamente para ser asesinado por orden del hermano de Cleopatra.

Con un metraje muy alargado, 243 minutos, Cleopatra es una epopeya donde, por quizás primera vez desde Salomón y la reina de Saba (1959), la protagonista femenina juega un rol tan fundamental y que, por muchos momentos, eclipsa sus contrapartidas masculinas.

A pesar de que visualmente reflejan una tensión muy pertinente e impactante, la difícil relación del personaje de Elizabeth Tylor con Burton provocó no pocas tensiones en el rodaje, mientras el 
complejo faraónico montado por la Fox iba a poco esquilmándose por conseguir fieles recreaciones como la del incendio de la biblioteca de Alejandría. Considerada hasta hace muy poco la producción más cara del cine, a pesar de no sacar todo el rendimiento ansiado en un primer momento, la Cleopatra de Mankiewicz ha ido ganando enteros y la categoría de clásico dentro de su género.

En un curioso paralelismo con su rol, el romance de Tylor, estando casada, con Burton, provocó un verdadero aluvión de críticas hacía la figura de la popular actriz, que llegó a incluso a ganarse la amonestación del mismísimo Vaticano. Esta leyenda negra de la femme fatale es la misma que persiguió a la madre de Cesarión hasta el final de sus días, aunque bien es verdad que motivos políticos y estratégicos pesaron mucho más que su supuesta promiscuidad sexual.

Nos es imposible pronunciarnos acerca de cómo hubiera derivado el papel de su amante en los planes de César, ya que su asesinato durante los idus de marzo del año 44 a.C., provocaron tanto la desaparición de sus proyectos como las disputas entre sus asesinos y los herederos de éste. Esto sucedió así fundamentalmente con su antiguo lugarteniente, Marco Antonio, así como con su sobrino/nieto, Cayo Octavio, el futuro primer emperador, Augusto.

Tras muchos ańos de pugna y repartos con otros protagonistas del Imperio Romano, como si fuese una partida de ajedrez, Octavio quedó con el control de la parte occidental y Antonio de la Oriental. Popular y con fama de ser un hombre tremendamente dionisíaco, a pocos romanos debió sorprender que cayese en las redes de la antigua amante de su comandante en jefe. Si la había citado en Tarso en el 41 a.C. para juzgarla por su falta de lealtad a la causa de Roma, a los postres de su reunión, ya le había prometido su protección y nuevos territorios.

No obstante, en una gran diferencia con el affaire mantenido previamente en Alejandría, en esta ocasión existía un rival implacable que no admitiría la presencia de alguien tan molesto como Cesarión para cuestionar su papel como heredero. Desde Roma y con un aparato propagandístico sin precedentes, el futuro emperador orquestó una sucesión de escritos que presentaron a la amante de su colega en el mando como La Reina de las Bestias y las brujas. De una manera muy hábil, Octavio buscó unificar sus legiones alrededor de una mujer extranjera y no en torno al popular Marco Antonio, a quien presentaban como un enamorado hechizado.

Es en este punto donde arranca esa imagen sexualmente perversa de nuestra protagonista. De haber ganado su flota en Actium, la historia se hubiera escrito de forma diferente, pero, con Marco Antonio suicidado, comprendiendo que no podría seducir a su tercer cónsul de Roma, solamente quedaba el golpe de la áspid. Densa, bajo la batuta de Alex North en su banda sonora y con excesivos dispendios, Cleopatra sigue siendo la narración de uno de los romances más sonoros de la Antigüedad. "Me han dicho que tu mujer en Roma duerme vestida...", llega a afirmar Tylor en una de las insinuaciones más claras de la libertad que el sediento Antonio encuentra en Oriente. 
Siempre bajo la sombra, para bien o para mal, de esta súper-producción, aún encontramos intentos de retomar a la pareja como la producción Marco Antonio y Cleopatra (1972), que pese a contar con la presencia de Charlton Heston como director y actor de la misma, encarnando a un enérgico Marco Antonio, no logra pasar de ser un péplum que, fue rodado en gran parte en España.

Con Hildegarde Neil como reina de Egipto y un reparto de secundarios que en su mayoría eran rostros muy conocidos de la escena española (Sancho Gracia, Juan Luis Galiardo, Carmen Sevilla...), el experimento no llega a cuajar y, aunque entretenido, no aporta ninguna novedad significativa en cuanto al personaje o la técnica de narrarlo.

Resucitada en algunas ocasiones de su descanso para aparición en telefilmes que generalmente buscan emular el arco argumental elaborado por Mankiewicz, sería de justicia destacar por su divertida irreverencia proyectos menos ambiciosos pero que al menos están revestidos de originalidad.

Así encontramos a Sofía Loren y Alberto Sordi en la comedia italiana Las noches de Cleopatra, en lo que sería una deformación cómica de la histórica pareja. Por otra parte, e incentivando aún más si cabe la clave divertida, encontramos el clásico de la animación Asterix y Cleopatra (Rene Goscinny, 1968).

Sí. Es probable que de haber sido su nariz más larga Cleopatra hubiera alcanzado menos incidencia en la Historia, las Artes, y el Cine. Pero parece que no es el caso. Así, en la mente de todo creador siempre existirá el fetiche de ella, alegoría de un Imperio milenario que se acaba, a medio camino también entre la reivindicación y perversión femeninas, eternamente romántica y deseada. Todo esto representa la "Reina del Nilo", un canon, en definitiva, para este tipo de cine que hemos tratado. 